\title{
PENINGKATAN HASIL BELAJAR IPA MELALUI PENDEKATAN KETERAMPILAN PROSES
}

\author{
Nurhakima Ritonga ${ }^{1}$ (nurhakimaritonga00@gmail.com) \\ Halimah Sakdiah Boru Gultom1, \\ Rahmi Nazliah', \\ ${ }^{1}$ Universitas Labuhanbatu
}

\begin{abstract}
ABSTRAK
Tujuan penelitian ini adalah untuk mengetahui kemampuan berpikir kritis dalam pembelajaran IPA melalui pendekatan keterampilan proses menggunakan penelitian tindakan kelas (PTK) yang diaplikasi dari siklus 1 dan berakhir pada siklus 2. Populasi pada penelitain ini seluruh siswa kelas VII SMP Negeri 2 Pangkatan menggunakan teknik purposive sample dengan jumlah sampel 35 siswa. Instrumen yang digunakan dalam penelitian yaitu pretest dan postest untuk mengukur hasil belajar siswa dan observasi untuk melihat keterampilan proses. Hasil penelitian ini menunjukkan adanya peningkatan kemampuan hasil belajar IPA dengan pendekan keterampilan proses dari 64,8 meningkat menjadi 81, 7. Dapat disimpulkan bahwa adanya peningkatan hasil belajar IPA melalui pendekatan keterampilan proses.
\end{abstract}

Kata Kunci : Hasil Belajar IPA, Keterampilan Proses, Pembelajaran IPA

\section{ABSTRACT}

The purpose of this study was to determine the ability to think critically in learning science through a process skills approach using classroom action research (PTK) which was applied from cycle 1 and ending in cycle 2. The population in this study was all students of grade VII of SMP Negeri 2 Pangkatan using purposive sample techniques with a sample of 35 students. The instruments used in the study are pretest and posttest to measure student learning outcomes and observation to see process skills. The results of this study indicate an increase in the ability of science learning outcomes by reducing process skills from 64.8 to 81, 7. It can be concluded that there is an increase in science learning outcomes through the process skills approach

Keywords: Science learning outcomes, Process Skills, Science Learning

\section{PENDAHULUAN}

Belajar IPA yang sebenarnya bukan merupakan penghafalan kata-kata yang ber-makna, melainkan merupakan hasil asosiasi dari pengalaman-pengalaman (Muakhirin, 2014). Belajar akan lebih bermakna jika anak mengalami apa yang dipelajarinya, bukan hanya mengetahuinya. Dari pengalamannya diharapkan siswa dapat memahami IPA secara lebih mendalam dan dapat diingat dalam waktu yang relatif lama. Untuk itu, guru perlu menerapkan strategi pembelaja-ran yang melibatkan siswa secara langsung dalam kegiatan belajar mengajar.

Proses pembelajaran di kelas diarahkan kepada kemampuan anak untuk menghafal informasi. Otak anak dipaksa untuk mengingat dan menimbun berbagai informasi tanpa dituntut memahami informasi yang diingatnya itu untuk menghubungkan dengan kehidupan sehari-hari. Akibatnya, ketika anak didik lulus dari sekolah mereka pintar teoritis tetapi mereka miskin aplikasi. Mata pelajaran biologi yang diajarkan di sekolah bertujuan untuk membekali siswa agar mampu mengembangkan kemampuan observasi dan eksperimentasi serta berfikir kritis. (Rahayu, 2011).

Proses pembelajaran IPA menekankan pada pemberian pengalaman langsung untuk mengembangkan kompetensi agar menjelajahi dan memahami alam sekitar secara ilmiah dan dilaksanakan secara inkuiri ilmiah (scientific inquiry) untuk menumbuhkan kemampuan berpikir, bekerja dan bersikap ilmiah serta mengkomunikasikannya sebagai aspek penting kecakapan hidup. Dalam rangka mewujudkan tujuan pem-belajaran IPA tersebut, maka menumbuhkan keterampilan berpikir siswa terutama kemam-puan berpikir kritis sangat diperlukan sehingga penguasaan suatu konsep oleh siswa tidak hanya berupa hafalan dari 
sejumlah konsep yang telah dipelajarinya, tetapi mereka juga mampu mene-rapkan konsep yang dimilikinya pada aspek yang lain. Untuk mewujudkan hal itu, maka sekolah dan guru sebagai komponen utama pendidikan perlu mengelola pembelajaran sesuai dengan prinsip-prinsip kegiatan belajar mengajar antara lain: (1) kegiatan berpusat pada siswa, (2) belajar melalui berbuat, (3) belajar mandiri dan belajar bekerja sama sehingga pembelajaran diharapkan tidak terfokus pada guru, tetapi bagaimana cara mengaktifkan siswa dalam belajarnya (student active learning) sehingga dibutuhkan pedekatan berupa keterampilan proses (Muslich, 2007).

Menurut Ahmatika (2016) Penggunaan pendekatan keterampilan dapat meningkatkan kemampuan berpikir siswa dalam pelajaran IPA. Hal ini terbukti adanya perkembangan aktivitas belajar dan proses pembelajaran IPA dengan menggunakan pendekatan keterampilan dapat dicapai. Begitu juga dengan Lubis, J. A., dan Harahap, R. (2018) bahwa ada peningkatan pemahaman konsep pembelajaran biologi siswa melalui model pendekatan keterampilan proses pada ekosistem di kelas X SMA Negeri 3 Padangsidimpuan.

Pendekatan keterampilan proses adalah pendekatan dalam proses belajar mengajar yang menekankan pada keterampilan memperoleh pengetahuan dan mengomunikasikan perolehannya itu. Keterampilan proses berarti pula sebagai perlakuan yang diterapkan dalam proses pembelajaran dengan mengunakan daya pikir dan kreasi secara efektif dan efisien guna mencapai tujuan (Mahmudah, 2017). Tujuan keterampilan proses adalah mengembangkan kreativitas peserta didik dalam belajar sehingga peserta didik secara aktif dapat mengembangkan dan menerapkan kemampuannya. Peserta didik belajar tidak hanya untuk mencapai hasil, melainkan juga belajar bagaimana belajar.

\section{METODE}

Penelitian ini dilaksanakan dibulan Ferbuari tahun 2019 di SMP Negeri 2 Pangkatan. Populasi dalam penelitaian ini seluruh siswa kelas VII VII-1 sampai VII-4 dan terdiri atas 4 kelas dengan jumlah total 98 orang. Sampel yang digunakan adalah adalah kelas VII 4 dengan teknik purposive sampling.
Jenis penelitian adalah penelitian tindakan kelas (PTK) yang memiliki empat tahapan yaitu: perencanaan, pelaksanaan, pengamatan, refleksi.

Adapun alur pelaksanaan tindakan dapat dilihat dari gambar 1 sebagai berikut:

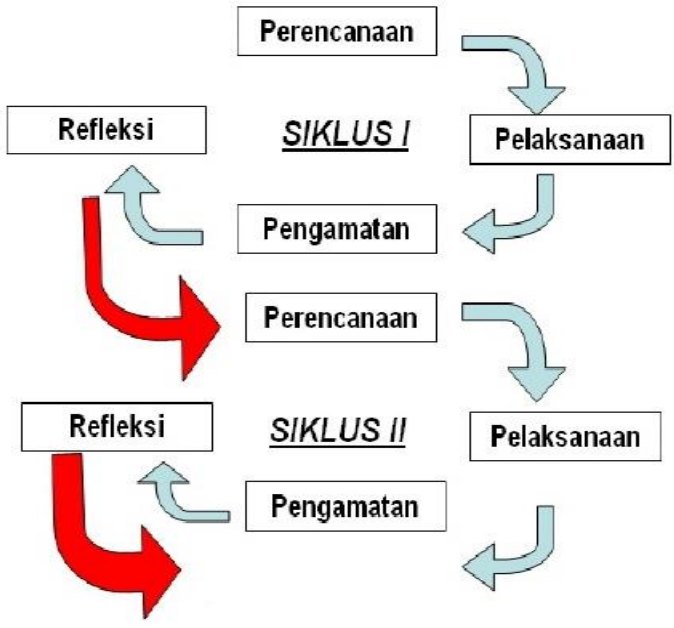

Gambar 1. Bagan Prosedur Penelitian Tindakan Kelas (Sumber: Buku Sanjaya, 2016)

Siklus 1: Pada awal siklus ini terlebih dahulu diadakan pretest untuk mengetahui tingkat kemampuan siswa sebebelum proses pembelajaran

Siklus 2: Dilaksanakan setelah melihat hasil refleksi pada siklus 1 dan hasil refleksi selanjutnya dapat dijadikan pedoman untuk melakukan perbaikan-perbaikan pada siklus berikutnya jika diperlukan.

Observasi digunakan untuk mengamati keterampilan proses selama proses pembelajaran dan diolah secara deskriptif kuantitatif dengan menggunakan skala penilaian. (Susanti, 2017). Pelaksanaan pembelajaran dengan penerapan kemampuan berpikir kritis melalui pendekatan keterampilan proses pada penelitian ini meliputi beberapa langkah yaitu 1) Persiapan yang dilakukan dengan mempersiapkan Rencana Program Kegiatan Pembelajaran Semester (RPKPS) dan Lembar Kegiatan Siswa (LKS); 2) Pelaksanaan pembelajaran dengan penerapan kemampuan berpikir kritis melalui pendekatan keterampilan proses dalam upaya mengembangkan kemampuan berpikir kritis; 3) Evaluasi dan Refleksi dengan subyek penelitian tentang hambatan yang ditemui dalam penerapan kemampuan berpikir kritis melalui pendekatan keterampilan proses dalam upaya mengembangkan kemampuan pendekatan 
keterampilan proses. Adapun kriteria dalam keterampilan proses dapat dilihat pada tabel 1.

Teknik pengumpulan data dalam penelitian ini menggunakan metode tes dan observasi dimana untuk mengukur hasil belajar kognitif siswa setelah tes akhir siklus, metode observasi untuk mengetahui tanggapan siswa terhadap pembelajaran yang telah dilakukan sehingga pendekatan keterampilan prosesnya tercapai.

Tabel 1. Skala Kriteria Ketempilan Proses

\begin{tabular}{lcc}
\hline No & Skala & Kriteria \\
\hline $\mathbf{1}$ & $0 \%-20 \%$ & Sangat Rendah \\
$\mathbf{2}$ & $21 \%-40 \%$ & Rendah \\
$\mathbf{3}$ & $41 \%-60 \%$ & Cukup \\
$\mathbf{4}$ & $61 \%-80 \%$ & Tinggi \\
$\mathbf{5}$ & $81 \%-100 \%$ & Sangat Tinggi \\
\hline
\end{tabular}

\section{HASIL DAN PEMBAHASAN}

Hasil penelitian ini dilaksanakan 2 tahapan keberhasilan dimulai dengan siklus 1 dan berakhir pada sisklus 2 kerana pada siklus 2 sudah terdapat tingkat keberhasilan ataupun peningkatan dengan menggunakan metode penelitian tingdakan kelas (PTK). Adapun hasil dari siklus 1 dan siklus 2 di SMP Negeri 2 Pangkatan pada pembelajaran IPA menunjukkan hasil belajar, ketuntasan klasikal dan rata-rata kelas dapat dilihat pada tabel 2 .

Tabel 2. Hasil belajar, Ketuntasan Klasikal dan RataRata

\begin{tabular}{ccc} 
Rata & & \\
\hline Keterangan & Siklus 1 & Siklus 2 \\
\hline Rata-rata & 74,81 & 81,76 \\
$\begin{array}{c}\text { Ketuntasan } \\
\text { Klasikal }\end{array}$ & $64,8 \%$ & $87 \%$ \\
\hline
\end{tabular}

Siklus 1 dilakasanakan evaluasi hasil belajar diperoleh nilai rata-rata 74,81 dan ketuntasan klasikal 64,8\%. Hasil observasi aktivitas siswa yang dilakukan oleh guru mata pelajaran pada siklus I pertemuan ke 1 diperoleh kriteria aktivitas siswa cukup baik, pertemuan ke-2 diperoleh kriteria aktivitas siswa cukup baik. Hasil observasi yang dilakukan guru mata pelajaran pada akhir siklus I diperoleh aktivitas guru berkriteria cukup. Rendahnya hasil belajar siswa disebabkan pembelajaran dengan model Jigsaw dengan pendekatan keterampilan proses dirasakan sedikit berbeda oleh siswa. Siswa tanpa langsung berikan materi, tetapi siswa diberikan kesempatan untuk mencari tahu konsep materi yang bersangkutan. Hasil penelitian siklus I menunjukkan bahwa hasil belajar siswa belum mencapai indikator keberhasilan karena siswa yang memperoleh nilai $\geq 75$ masih berada di bawah $85 \%$ dan aktivitas peneliti kriteria belum mencapai indikator keberhasilan minimal berkriteria baik. Karena hasil belajar siswa masih belum mencapai indikator keberhasilan dan aktivitas guru belum mencapai indikator (Azizirrahim et al, 2017).

Dalam pola interaksi belajar mengajar (pembelajaran) siswa masih sangat beragam, beberapa guru menyebutkan masih ada jarak antara yang pandai dan kurang pandai, masih banyak siswa mengalami kesulitan interaksi akademik (pasif dan hanya mendengarkan saja), adanya jarak hubungan antara guru dan murid. Usaha yang dilakukan untuk mengatasi adalah melalui memperbanyak interkasi dengan siswa, menggunakan metode yang dapat mengaktifkan siswa, melakukan pengakraban terhadap siswa dan menggunakan waktu luang untuk pembinaan. Tingkat kesulitan yang dihadapi guru berkaitan dengan pola interaksi akademik (pembelajaran (Subadi, 2010).

Pada siklus II kemampuan berpikir kritis siswa dalam pembelajaran IPA dikembangkan dengan menggunakan keterampilan proses dari mulai perencanaan, pengamatan, pelaksanaan dan Refleksi sehingga mengalami peningkatan yang dapat dilihat pada tabel 2. Hasil penelitian siklus II menunjukkan bahwa hasil belajar siswa sudah mencapai indikator keberhasilan karena siswa yang memperoleh nilai $\geq 75$ sudah berada di atas $85 \%$ dan aktivitas peneliti kriteria sudah mencapai indikator keberhasilan berkriteria baik

Pada pendekatan keterampilan proses meliputi mengamati/ observasi, interpretasi/ mengelolah, merumuskan hipotesis, melakukan eksperimen, menyimpulkan dan mengkomunikasikan dapat diamati pada penelitian ini dan dianalisis secara deskriptif dengan tujuan untuk mengetahui indikator mana ang dimiliki siswa dan indikator mana yang perlu dibina dan dikembangkan,. Kriteria penilaian meliputi sangan tinggi, tinggi, cukup rendah, rendah dan sangat rendah. Rata-rata siswa dapat dilihat pada tabel 3.

Pada tabel 3 dibawah terlihat jelas perbedaan indikator-indikator dari keterampilan siswa dalam poin (1). Keterampilan siswa dalam mengamati dengan kriteria tinggi dan mengalami 
peningkatan dari 70,83 menjadi 82,52. (2). nilai walaupun masih dengan kreteria yang sama Keterampilan interprestasi mengalami kenaikan $\quad$ yaitu cukup dari 70 menjadi 76.

Tabel 3. Rata-Rata Aspek Kriteria Keterampilan Proses

\begin{tabular}{lcccc}
\hline \multicolumn{1}{c}{ Keterampilan proses } & \multicolumn{2}{c}{ Eksperimen } & \multicolumn{2}{c}{ Kontrol } \\
\cline { 2 - 5 } Mengamati & Rata-rata & kriteria & Rata-rata & kriteria \\
Interpretasi & 82,56 & $\mathrm{~T}$ & 70,83 & $\mathrm{C}$ \\
Hipotesis & 76 & $\mathrm{C}$ & 70 & $\mathrm{C}$ \\
Eksperimen & 86,05 & $\mathrm{~T}$ & 75 & $\mathrm{C}$ \\
Menyimpulkan dan mengomuniasikan & 85,47 & $\mathrm{~T}$ & 77,98 & $\mathrm{C}$ \\
Rata-Rata Nilai Siswa & 90 & $\mathrm{ST}$ & 76,19 & $\mathrm{C}$ \\
\hline
\end{tabular}

(3). Keterampilan Hipotesis mengalami peningkatan dari nilai 75 menjadi 86,05 dengan kriteria tinggi. (4) Keterampilan eksperimen memiliki kriteria tinggi yaitu 85,47 dari yang sebelumnya dengan nilai 77,98 (5). Keterampilan mengkomikasi dan menyimpulkan mengalami perubahan yang sangat signifikan dari kriteria cukup $(76,19)$ menjadi kriteria sangat tinggi $(90)$. Menurut Wati, dkk (2016) Karakteristik modul IPA berbasis keterampilan proses sains dengan tema tekanan yang terdiri dari mengamati, mengklasifikasi, mengkomunikasi, mengukur, memprediksi dan menyimpulkan. Modul ini menggunakan model keterpaduan connectedpada materi tekanan menggabungkan antara materi fisika, biologi dan kimia karena modul ini dibuat sesuai dengan kurikulum 2013 dimana pembelajaran IPA bersifat terpadu. Hasil penelitian menunjukkan bahwa modul sangat membantu siswa belajar mandiri, membantu dan diperlukan siswa sebagai panduan belajar dimana dilengkapi dengan eksperimeneksperimen sederhana. Pengembangan modul IPA berbasis KPS ini dinilai efektif karena selain hasil belajar siswa yang meningkat, keterampilan proses sains dari siswa itu sendiri mengalami peningkatan. Adapun rata-rata total siswa dapat dilihat pada gambar grafik 1.

Pada gambar dibawah terdapat perbedaan nilai rata-rata total siswa yang menggunakan pendekatan keterampilan proses dan tanpa pendekatan keterampilan proses, nilai yang menggunakan pendekatan mengalami peningkatan dari pada yang tanpan menggunkan pendekatan. Rata-rata nilai kedua kelas pada indikator tersebut berada pada kriteria yang berbeda, yakni pada kriteria sangat tinggi.

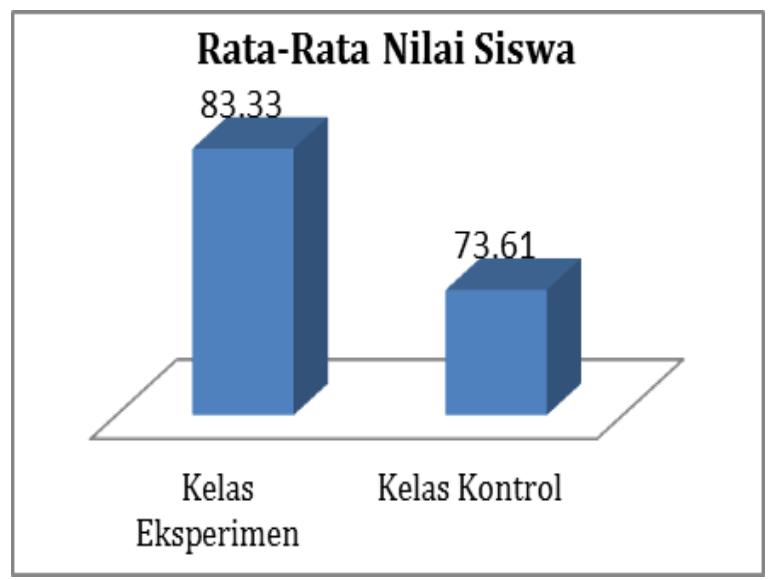

Gambar 1. Rata-Rata Nilai Siswa.

Hal ini dapat terjadi karena pada penelitian ini, pembelajaran lebih terfokus pada pengembangan keterampilan proses observasi, hipotesis, melakukan eksperimen dan mengkomunikasikan simpulan dari hasil eksperimen siswa sehingga pengembangan keterampilan proses sains klasifikasi dan keterampilan proses sains interpretasi siswa masih kurang dilatih (Deta, et al, 2013). Selain itu, untuk dapat mengembangkan keterampilan proses sains inter-pretasi, guru baik didalam kelas maupun di lapangan harus lebih menguasai materi berkaitan agar dapat memandu siswa dengan baik (Adnyani, et al, 2018).

\section{PENUTUP}

Berdasarkan rumusan masalah dapat disimpulkan bahwa adanya peningkatan hasil belajar IPA melalui pendekatan keterampilan proses.

\section{REFERENSI}

Adnyani, I. W., Pujani, N. M., \& Juniartina, P. P. (2018). Pengaruh Model Learning Cycle 7E Terhadap Keterampilan Berpikir Kritis Siswa. Jurnal Pendidikan dan Pembelajaran Sains Indonesia (JPPSI), 1(2), 56-67. 
Ahmatika, D. (2016). Peningkatan Kemampuan Berpikir Kritis Siswa Dengan Pendekatan Inquiry/Discovery. Euclid, 3(1), 394-403. http://dx.doi.org/10.33603/e.v3i1.324

Azizirrahim, E., Sutrio, S., \& Gunawan, G. (2017). Penerapan Pendekatan Keterampilan Proses Sains dalam Model Pembelajaran Guided Discovery untuk Meningkatkan Hasil Belajar IPA Fisika pada Siswa Kelas VIIA SMPN 8 Mataram Tahun Ajaran 2015/2016. Jurnal Pendidikan Fisika dan Teknologi,1(4), 272275.

Deta, U. A., \& Widha, S. (2013). Pengaruh Metode Inkuiri Terbimbing dan Proyek, Kreativitas, serta Keterampilan Proses Sains terhadap Prestasi Belajar Siswa. Jurnal Pendidikan Fisika Indonesia, 9(1), 28-34.

Iskandar, S. M. (2016). Pendekatan Keterampilan Metakognitif Dalam Pembelajaran Sains di Kelas. Erudio Journal of Educational Innovation, 2(2), 13-20.

Lubis, Jalilah. A., dan Harahap, Risnawati. (2018). Penerapan Pendekatan Keterampilan proses Untuk Meningkatkan Pemahaman Konsep Pembelajaran Biologi Siswa di SMA Negeri 3 Padangsidimpuan. Jurnal Biolokus, Vol.1 (2) 101-108

DOI

http://dx.doi.org/10.30821/biolokus.v1i2.35 $\underline{0}$

Mahmudah, L. (2017). Pentingnya Pendekatan Keterampilan Proses Pada Pembelajaran IPA di Madrasah. ELEMENTARY: Islamic Teacher Journal, 4(1), 167-187.

Muakhirin, B. (2014). Peningkatan Hasil Belajar IPA Melalui Pendekatan Pembelajaran Inkuiri Pada Siswa SD. Jurnal Ilmiah Guru Caraka Olah Pikir Edukatif, 1, 51-57.

Muslich. (2007). KTSP Pembelajaran Berbasis Kompetensi dan Kontekstual. Jakarta: Bumi Aksara.

Rahayu, E. (2011). Pembelajaran sains dengan pendekatan keterampilan proses untuk meningkatkan hasil belajar dan kemampuan berpikir kreatif siswa. Disertasi. Universitas Negeri Semarang.

Sanjaya, D. H. W. (2016). Penelitian Tindakan Kelas. Jakarta: Prenada Media.
Subadi, T. (2010). Lesson Study Berbasis PTK (Penelitian Tindakan Kelas). Surakarta: Badan Penerbit FKIP UMS.

Susanti, E. (2017). Penerapan Model Pembelajaran Probing-Prompting untuk Meningkatkan Kemampuan Berpikir Kritis Matematis Siswa Kelas XI. IPA MAN 1 Kota Bengkulu. Jurnal Pendidikan Matematika Raflesia, 2(1), 96-107..

Wardani, S., Widodo, A. T., \& Priyani, N. E. (2009). Peningkatan Hasil Belajar Siswa Melalui Pendekatan Keterampilan Proses Sains Berorientasi Problem-Based Instruction. Jurnal Inovasi Pendidikan Kimia, 3(1), 391-399.

Wati, W., \& Novianti, N. (2016). Pengembangan Rubrik Asesmen Keterampilan Proses Sains pada Pembelajaran IPA SMP.Jurnal Ilmiah Pendidikan Fisika Al-Biruni, 5(1), 131-140. 